\title{
Optimal Utilization of Hydro-Energetic Potential of Flows on
}

\section{Morača River}

\section{Ratko Mitrović}

Abstract: The process of finding optimal solution for utilization of hydro-energetic potential of a river flow is a very complex procedure, because it is necessary to find a compromise between an energetically optimal solution and a solution with lower negative influence on the environment and sociological conditions, which is often contradictory in practice. In order to show more precisely the complexity in choosing an optimal solution for utilization of hydro-energetic potential of a river flow, a mathematical model of multi-criteria optimization and multi-criteria rating for different variants of utilization of the River Morača basin is presented in this paper. For the process of multi-criteria optimization, a complete software packages and large documentation as well as preliminary projects for planned hydropower plants have been used. The aim is to reach an optimal utilization of hydro-energetic potential of a river flow, especially in cases when the existing investigations do not give priority to a particular variant, and the hydropower plants need to be constructed in near future.

Key words: Hydro-energetic potential, small hydropower, multi-criteria optimization, Morača river basin, Montenegro

\section{Introduction}

This paper discusses a complex mission of optimization of hydro-energetic potential utilization of a specific river flow. In this context, the optimization is only the means to provide a decision making utility about the effects and consequences of particular possible decisions. To find the optimal solution for hydro-energetic utilization of a river, we present a mathematical model of multicriteria optimization and rating which can be successfully used in finding an optimal solution for hydroenergetic utilization of a specific water flow.

Many solutions these days cannot be applied in practice for hydro-energetic potential utilization. The most common reasons are the increased influence of non-governmental sector and other associations for environment protection on development of energetic sector, on the environment, difficulties in regulation of legal property relations, demographic nature problems, etc. In order to make a concrete decision about the construction of big reservoirs which inundate populated areas and bountiful scenic areas, a prior analysis should be conducted in order to persuade the people that the utilization of hydro-energetic potential of a river flow has optimal solution regarding negative influence on the environment, energetic usage, sociological conditions, etc.

To simplify the complex process of multi-criteria optimization and rating the modeling process is presented through the practical example of finding an optimal solution for the hydro-energetic utilization of the Morača River in Montenegro. Till now, an optimal variant of hydro-energetic utilization has not been found, though many activities for the construction of hydropower plants at this water flow have been undertaken. A multi-criteria optimization, which implies all important factors relevant for making decisions, must be previously performed in order to make a appropriate decision of a specific variant and get supportive hands for the construction of hydroenergetic objects..

\section{AnalysisofVariantSolutionsofHydroenergetic Potential Utilization of the Morača River}

The data used are mainly secondary, which are older than 20 or more years old. Therefore, many solutions proposed may not be used in today's conditions, because there is a disharmony between the solutions from the period of Communism. To make and implement the decisions about the formation of big reservoirs and inundations of entire areas, is nowadays rather hard to achieve primarily because of bigger influence of non-governmental and other associations for the environment protection on the development of energy sector. Moreover, there are negative evidences that influence existing reservoirs on the environment in Montenegro, as well as difficulties with regulations of legal property relations because of higher prices of real estate in Montenegro.

In last 20 years in this and neighbouring European countries huge changes have occurred in all sectors; therefore it is necessary to find a compromise between previously proposed solutions of utilization of this water flow and new conditions. This investigation is in designed to search for these solutions, and the comparative analysis of proposed variants from the current Water Economy Base and new solutions proposed by the author of this paper will give an optimal solution. 


\begin{tabular}{|c|c|c|c|c|c|c|c|c|c|c|}
\hline No. & $\begin{array}{l}\text { Name } \\
\text { of HPP }\end{array}$ & $\begin{array}{l}\text { Type } \\
\text { of HPP }\end{array}$ & $\begin{array}{l}\text { Average } \\
\text { annual } \\
\text { water } \\
\text { flow } \\
\text { Qav. }\end{array}$ & $\begin{array}{l}\text { Install- } \\
\text { water } \\
\text { ation } \\
\text { flow } \\
\text { Qinst. }\end{array}$ & $\begin{array}{l}\mathrm{Hg} \\
\text { (gross) }\end{array}$ & $\begin{array}{l}\mathrm{Hn} \\
\text { (net) }\end{array}$ & $\begin{array}{l}\text { Installa } \\
\text {-tion } \\
\text { power } \\
\text { Ni (MW) }\end{array}$ & $\begin{array}{l}\text { Produc } \\
\text {-tion } \\
\text { E year }\end{array}$ & $\begin{array}{l}\text { Annual } \\
\text { Volume } \\
\text { of accumu } \\
\text {-lation Va } \\
\left(1.0 \times 10^{6} \mathrm{~m} 3\right)\end{array}$ & $\begin{array}{l}\text { Normal } \\
\text { back } \\
\text {-water } \\
\text { level }\end{array}$ \\
\hline & & & $\mathrm{M}^{3} / \mathrm{s}$ & $\mathrm{M}^{3} / \mathrm{s}$ & $\mathrm{m}$ & $\mathrm{m}$ & MW & GWh & $\mathrm{M}$ (million) $\mathrm{m}^{3}$ & m.n.m. \\
\hline 1. & LJevišta & Der. & 3.56 & 20 & 300.5 & 277.1 & 47 & 73.4 & 27 & 1028 \\
\hline 2. & Krušev lug & Der. & 7.06 & 35 & 105.6 & 94.1 & 27 & 49.5 & 29 & 590 \\
\hline 3. & Ljuta & Der. & 9.78 & 50 & 159 & 155 & 60 & 113 & 45 & 463 \\
\hline 4. & Andrijevo & Dam. & 37.8 & 120 & 117 & 115 & 127 & 323.7 & 250 & 285 \\
\hline
\end{tabular}

The tributaries of the River Morača

\begin{tabular}{|l|l|l|l|l|l|l|l|l|l|l|}
\hline 5. & Ibrija & Der. & 1.27 & 6 & 158.2 & 150.4 & 7 & 14.2 & 8.4 & 481 \\
\hline 6. & Velje Duboko & Der. & 2 & 10 & 549 & 492 & 40 & 73.3 & 13.5 & 846 \\
\hline & SUM & & & & & & $\mathbf{3 0 8}$ & $\mathbf{6 4 7 . 1}$ & $\mathbf{3 7 3 . 9}$ & \\
\hline
\end{tabular}

Table 1. Variant 1 Predicts the Construction of Big HPP Andrijevo with the Normal Backwater Level 285 m ASL, and Upstream Hydro Power Plants Ljevišta, Krušev Lug, Ljuta.

\begin{tabular}{|c|c|c|c|c|c|c|c|c|c|c|}
\hline No. & $\begin{array}{c}\text { Name of } \\
\text { HPP }\end{array}$ & $\begin{array}{c}\text { Type of } \\
\text { HPP }\end{array}$ & $\begin{array}{c}\text { Average } \\
\text { annual } \\
\text { water } \\
\text { flow } \\
\text { Qav. }\end{array}$ & $\begin{array}{c}\text { Install- } \\
\text { ation } \\
\text { water } \\
\text { flow } \\
\text { Qinst. }\end{array}$ & $\begin{array}{c}\mathrm{Hg} \\
\text { (gross) }\end{array}$ & $\begin{array}{c}\mathrm{Hn} \\
\text { (net) }\end{array}$ & $\begin{array}{l}\text { Installa- } \\
\text { tion } \\
\text { power } \\
\mathrm{Ni}(\mathrm{MW})\end{array}$ & $\begin{array}{c}\text { Annual } \\
\text { Produc- } \\
\text { tion Eyear } \\
(\mathrm{kWh}) .\end{array}$ & $\begin{array}{c}\text { Volume of } \\
\text { accumu- } \\
\text { lation Va } \\
\left(1.0 \times 10^{6} \mathrm{~m}^{3}\right)\end{array}$ & $\begin{array}{c}\text { Normal } \\
\text { back- } \\
\text { water } \\
\text { level }\end{array}$ \\
\hline & & & $\mathrm{M}^{3} / \mathrm{s}$ & $\mathrm{M}^{3} / \mathrm{s}$ & $\mathrm{m}$ & $\mathrm{m}$ & MW & GWh & $\mathrm{Mm}^{3}$ & m.n.m. \\
\hline \multicolumn{11}{|c|}{ Main course of the river Morača } \\
\hline 1. & Dubravica & Prib. & 9.78 & 50 & 146 & 144 & 60 & 104.9 & 100 & 500 \\
\hline 2. & Grla & Prib. & 9.78 & 30 & 40 & 38 & 10 & 27.7 & 2 & 335 \\
\hline 3. & Andrijevo & Prib. & 37.8 & 120 & 85 & 83 & 127 & 233.6 & 100 & 250 \\
\hline \multicolumn{11}{|c|}{ Tributaries of the river Morača } \\
\hline 4. & Ibrija & Der. & 1.27 & 6 & 231 & 229.6 & 12 & 21.7 & 8.4 & 481 \\
\hline 5. & Velje Duboko & Der. & 2 & 10 & 550 & 538.4 & 46 & 80.2 & 1.6 & 800 \\
\hline \multirow[t]{2}{*}{6.} & Sjevernica & Prib. & 2 & 10 & 100 & 98 & 9 & 14.6 & 30 & 350 \\
\hline & SUM & & & & & & 264 & 482.7 & 262 & \\
\hline
\end{tabular}

Table 2. Variant 2 Predicts HPP Andrijevo with the Normal Backwater Level $250 \mathrm{~m}$ asl, Construction of the Same Downstream Water Power Plants on the Basic Water Stream and on the Affluents as in Variant 1, while HPP Grla and Dubovica are Planned Upstream. Type of Hydro Power Plants: Der. = HPP with Derivation (with long penstock); Prib.= HPP with Power House Close to the Dam.

\begin{tabular}{|c|c|c|c|c|c|c|c|c|c|c|}
\hline No. & $\begin{array}{c}\text { Name of } \\
\text { HPP }\end{array}$ & $\begin{array}{c}\text { Type of } \\
\text { HPP }\end{array}$ & $\begin{array}{c}\text { Average } \\
\text { annual } \\
\text { water } \\
\text { flow } \\
\text { Qav. }\end{array}$ & $\begin{array}{c}\text { Install- } \\
\text { ation } \\
\text { water } \\
\text { flow } \\
\text { Qinst. }\end{array}$ & $\begin{array}{c}\mathrm{Hg} \\
\text { (gross) }\end{array}$ & $\begin{array}{c}\mathrm{Hn} \\
\text { (net) }\end{array}$ & $\begin{array}{c}\text { Installa- } \\
\text { tion } \\
\text { power } \\
\text { Ni (MW) }\end{array}$ & $\begin{array}{l}\text { Annual } \\
\text { Produc- } \\
\text { tion Eyear } \\
\text { (kWh). }\end{array}$ & $\begin{array}{c}\text { Volume of } \\
\text { accumu- } \\
\text { lation } \\
\text { Va } \\
\left(1.0 \times 10^{6} \mathrm{~m}^{3}\right)\end{array}$ & $\begin{array}{c}\text { Normal } \\
\text { back- } \\
\text { water } \\
\text { level }\end{array}$ \\
\hline & & & $\mathrm{M}^{3} / \mathrm{s}$ & $\mathrm{M}^{3} / \mathrm{s}$ & $\mathrm{m}$ & $\mathrm{m}$ & MW & GWh & $\mathrm{Mm}^{3}$ & m.n.m. \\
\hline \multicolumn{11}{|c|}{ Main course of the river Morača } \\
\hline 1. & Luta & Der. & 3.56 & 20 & 300.5 & 277.1 & 47 & 73.4 & 27 & 1028 \\
\hline 2. & Dubravica & Prib. & 9.78 & 50 & 146 & 144 & 60 & 104.9 & 100 & 500 \\
\hline 3. & Grla & Prib. & 9.78 & 30 & 40 & 38 & 10 & 27.7 & 2 & 335 \\
\hline 4. & Andrijevo & Prib. & 38 & 120 & 98 & 95 & 130 & 267 & 150 & 265 \\
\hline \multicolumn{11}{|c|}{ Tributaries of the river Morača } \\
\hline 4. & Ibrija & Der. & 1.27 & 6 & 215 & 213 & 11.1 & 20.1 & 8.4 & 481 \\
\hline 5. & Velje Duboko & Der. & 2 & 10 & 535 & 521 & 45.3 & 78.9 & 1.6 & 800 \\
\hline \multirow[t]{2}{*}{6.} & Sjevernica & Prib. & 2 & 10 & 100 & 98 & 9 & 14.6 & 30 & 350 \\
\hline & SUM & & & & & & 265.4 & 513.5 & 292 & \\
\hline
\end{tabular}

Table 3. Variant 3 is the Same as Variant 2, but there is an Additional Possibility of the Reservoir Construction for HPP Ljevišta with the Normal Backwater Level $1028 \mathrm{~m}$ asl. 
According to Strategy of Energetic Development in Montenegro, by the year 2025 the construction of hydropower plants, such as HPP (Hydro Power Plant) Andrijevo, HPP Milunovići, HPP Rafailovići and HPP Zlatica, was planned on the river Morača, but in this strategy the detailed analysis indicating the accepted variant from the current Water Economy Base of Montenegro was not presented. The question is: Is it Variant 1, which implies the creation of big reservoir, with normal level 285 m.n.m. (Veliko Andrijevo), or Variant 2, with normal level of the same accumulation 250 m.n.m? This delicate matter was avoided even in Water Economy Base of Montenegro and in Strategy of Energetic Development of Montenegro by 2025; therefore, both were only presented as possible variants of utilization of this very important hydroenergetic potential. The expert team from the Institute Jaroslav Černi, because of inadequacy of previously mentioned variants, suggests Variant 3 with normal level of accumulation Andrijevo 265 m.n.m. (Divac et al 2001, Đorđević and Šaranović 2004, and Đorđević2001)/.

Apart from the above mentioned variants even the variants which provide transfer of upper basin water of the river Morača and formation of big reservoir on the River Mrtvica in Velje Duboko appear. These are Variants 4 and 5, which provide transfer of upper basin water of the river Morača into big reservoir of Velje Duboko, as well a smaller accumulation Bijeli Nerini and construction of two hydropower plants HPP Velje Duboko and Bijeli Nerini (Brečević et al 2007, Đorđević 2003, Đorđević and Šaranović 2007). The basic data for these variants are shown in Table 4 and Table 5.

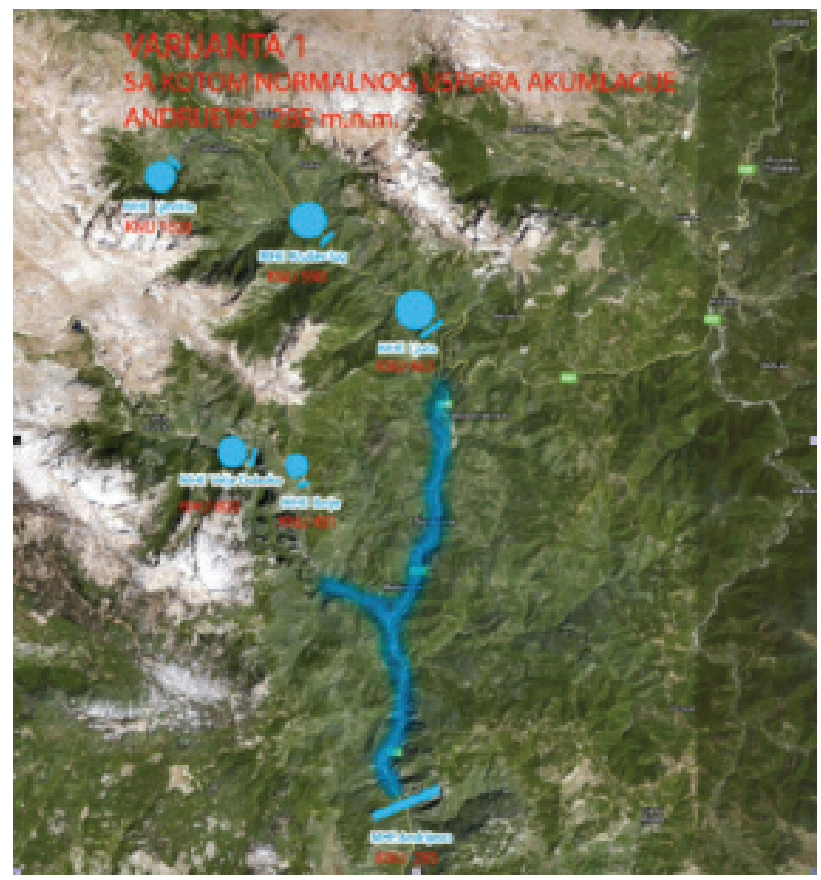

Figure 1. Main Course and Tributaries of the River Morača, Montenegro: Variant 1.

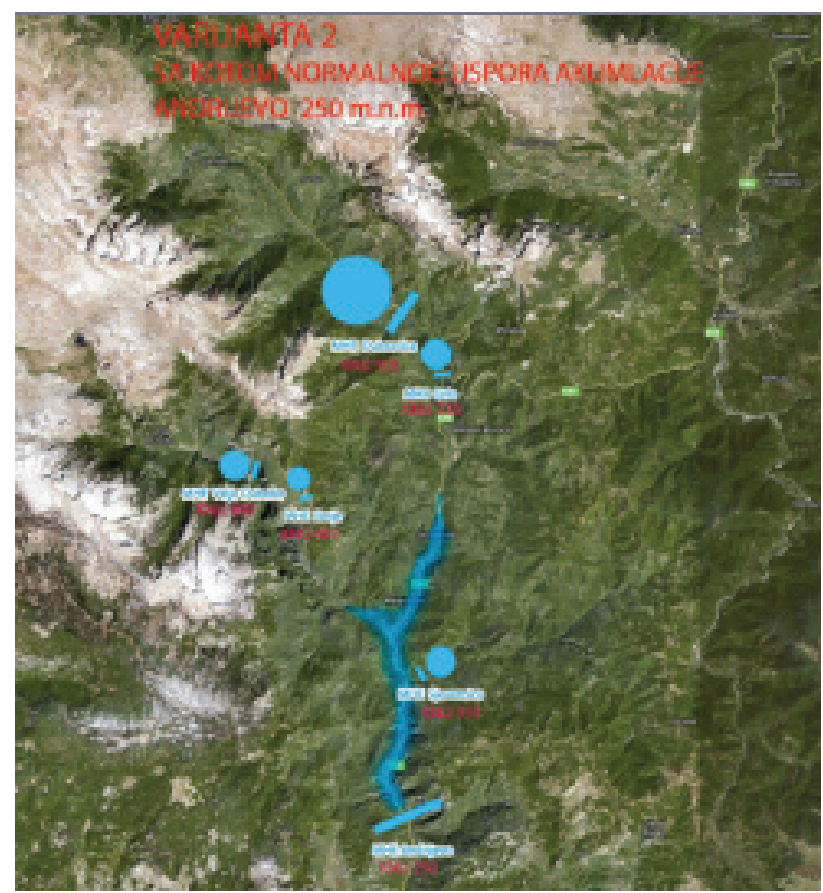

Figure 2. Main Course and Tributaries of the River Morača, Montenegro: Variant 2.

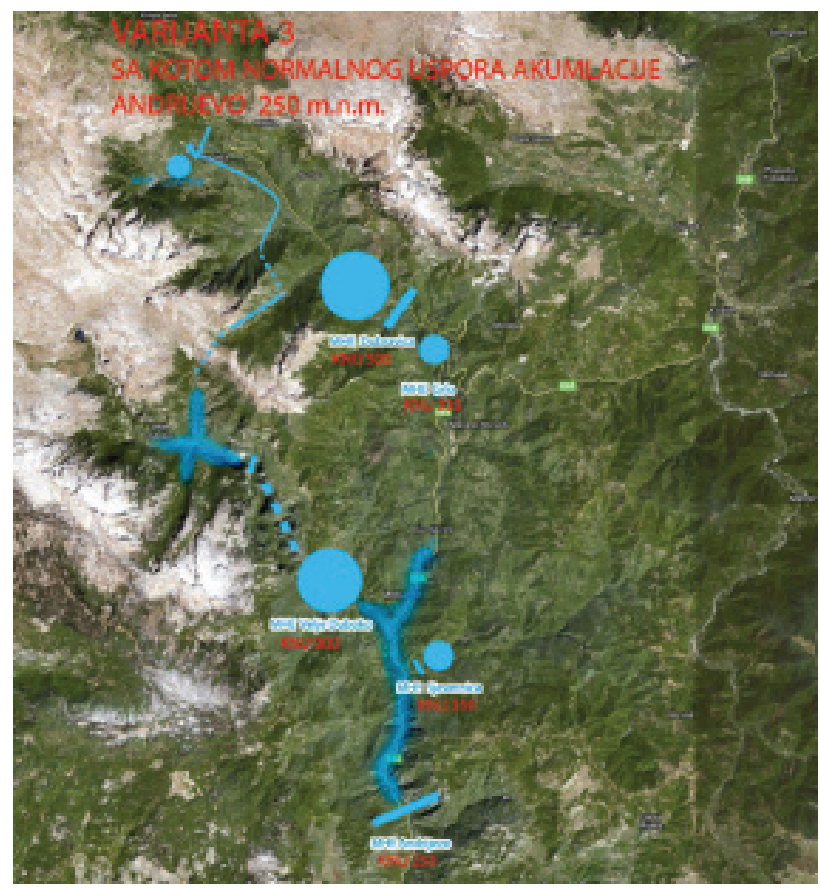

Figure 3. Main Course and Tributaries of the River Morača, Montenegro: Variant 3.

The original Variant 6 and Variant 7 are similar to Variants 4 and 5, but in this case the reservoir Bijeli Nerini and hydropower plant Bijeli Nerini are avoided and the construction of hydropower plant Velje Duboko, which implies direct water flow from the reservoir Velje Duboko into the reservoir Andrijevo, is planned. The basic data of Variant 6 and Variant 7 are shown in Table 6 and 7 (Đorđević 1990, Divac et al 2001, Opricović 1986). 


\begin{tabular}{|c|c|c|c|c|c|c|c|c|c|}
\hline No. & $\begin{array}{c}\text { Name of } \\
\text { HPP }\end{array}$ & $\begin{array}{c}\text { Average } \\
\text { annual } \\
\text { water } \\
\text { flow } \\
\text { Qav. }\end{array}$ & $\begin{array}{l}\text { Install- } \\
\text { ation } \\
\text { water } \\
\text { flow } \\
\text { Qinst. }\end{array}$ & $\underset{\text { (gross) }}{\mathrm{Hg}}$ & $\begin{array}{c}\mathrm{Hn} \\
\text { (net) }\end{array}$ & $\begin{array}{l}\text { Installa- } \\
\text { tion } \\
\text { power } \\
\mathrm{Ni}(\mathrm{MW})\end{array}$ & $\begin{array}{l}\text { Annual } \\
\text { Produc- } \\
\text { tion Eyear } \\
\text { (kWh). }\end{array}$ & $\begin{array}{l}\text { Volume of } \\
\text { accumu- } \\
\text { lation } \\
\text { Va } \\
\left(1.0 \times 10^{6} \mathrm{~m}^{3}\right)\end{array}$ & $\begin{array}{c}\text { Normal } \\
\text { back- } \\
\text { water } \\
\text { level }\end{array}$ \\
\hline & & 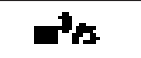 & No & n & $\mathbf{m}$ & $\mathrm{mw}$ & ent & $\mathbf{A} \mathbf{m}^{\mathbf{P}}$ & menne \\
\hline 1. & Velje duboko & 7.06 & 40.0 & 535.0 & 479 & 161.0 & 260.0 & 90.0 & 922.0 \\
\hline 2. & Bijeli Nerini & 19.39 & 60.0 & 125.0 & 120.0 & 61.0 & 165. & 1.5 & 380.0 \\
\hline 3. & Grlo & 5.43 & 20.0 & 180.0 & 154.0 & 26.0 & 68.0 & 46.0 & 452.0 \\
\hline 4. & Andrijevo & 37.8 & 120 & 85.0 & 85.0 & 127.0 & 233.6 & 100.0 & 250 \\
\hline 5. & Trebješka & 1.3 & 5.0 & 290.0 & 284.0 & 12.0 & 26.0 & 4.0 & 700.0 \\
\hline 6. & Celina & 1.0 & 4.0 & 115.0 & 106.0 & 4.0 & 6.0 & 1.5 & 520.0 \\
\hline \multirow[t]{2}{*}{7.} & Sjevernica & 5.15 & 12.0 & 124.0 & 115.0 & 12.0 & 42.9 & 2.0 & 400.0 \\
\hline & SUM & & & & & 395.0 & 809.5 & 245.0 & \\
\hline
\end{tabular}

Table 4. Variant 4 Predicts the Transfer of Upper Basin Water of the River Morača and Formation of Big reservoir on the River Mrtvica in Velje Duboko and Small Downstream reservoir Bijeli Nerini and with Normal Backwater Level of reservoir Andrijevo $250 \mathrm{~m}$ asl.

\begin{tabular}{|c|c|c|c|c|c|c|c|c|c|}
\hline ne & the of & 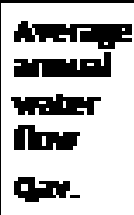 & 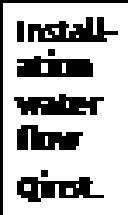 & it & $\begin{array}{l}\text { ln } \\
\text { |ninit }\end{array}$ & 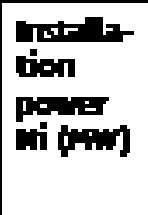 & 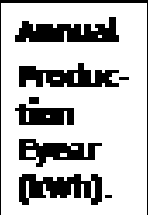 & 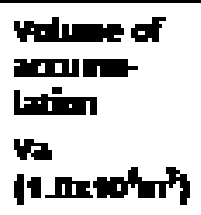 & 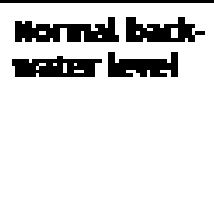 \\
\hline & & מ & $n^{3}$ & $\square$ & $\mathbf{m}$ & $\mathrm{nw}$ & ent & $M \boldsymbol{r}^{*}$ & anne \\
\hline 1. & $\begin{array}{l}\text { Velje } \\
\text { difico }\end{array}$ & 7.05 & 40.0 & 535.0 & 47 & 161.0 & 260.0 & m.0 & m0 \\
\hline 2 & $\begin{array}{l}\text { Ejji } \\
\text { Nimini }\end{array}$ & 17.3 & 60 & 110.0 & 104.0 & 53.0 & 138.0 & 1.5 & s:0.0 \\
\hline 3. & Gra & 5.43 & no.0 & 100.0 & 154.0 & Ino & Ga & 46.0 & Gro \\
\hline 4. & Andrijevl & 37. & 120 & E:se & BE.O & 150.0 & 267.0 & 150.0 & 205 \\
\hline 5. & Trebj:an & 1.3 & 5.0 & $2 \times 0.0$ & 24.0 & 120 & 200 & 4.0 & ताD \\
\hline 6 & Cedifa & 1.0 & 4.0 & 115.0 & tob.a & 10 & 40 & 1.5 & 5e्l.0 \\
\hline \multirow[t]{2}{*}{7.} & Sjevenion & 5.15 & 120 & 1240 & 115.0 & 120 & a旦9 & 20 & 4⿴囗十丁 \\
\hline & \multicolumn{5}{|l|}{ sum } & 4100 & : & 73됴 & \\
\hline
\end{tabular}

Table 5. Variant 5 Predicts the Transfer of Upper Basin Water of the River Morača and Formation of Big reservoir on the River Mrtvica in Velje Duboko and Small Downstream reservoir Bijeli Nerini and with Normal Backwater Level of reservoir Andrijevo $265 \mathrm{~m}$ asl.

The variants downstream of the hydropower plant HPP Andrijevo were not analyzed, because the suggested solutions presented in Water Economy Base of Montenegro in all variants are optimal.

This project is envisioned very ambitiously because it affects the core of energetic development, especially having in mind that the project of the Strategy of Energetic Development in Montenegro by 2025 predicts only the construction of bigger hydropower plants on the river Morača and only one more hydropower plant Komarnica. With this strategy the priority hasn't been given to variant solutions for the construction of hydropower plants on the Morača, but the solutions are mostly based on the data from current Water Economy Base of Montenegro. The in-depth analysis in order to favour certain proposed variant solutions hasn't been performed until now, probably due to the complex analysis of the problem, as well as its implementation in practice. 


\begin{tabular}{|c|c|c|c|c|c|c|c|c|c|}
\hline n. & M & 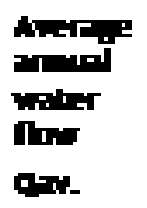 & 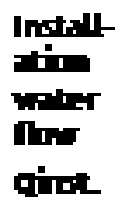 & (1, & $\begin{array}{l}\text { ln } \\
\text { lnet }\end{array}$ & 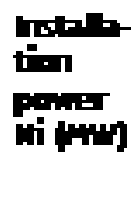 & 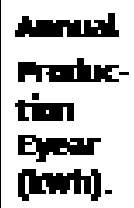 & 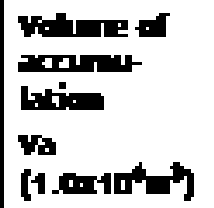 & Mormat batk \\
\hline & & $\omega^{\prime}$ & $m^{\prime} s$ & n & $\mathbf{m}$ & min & Gih & $\boldsymbol{m}^{7}$ & menn \\
\hline 1. & velje & 7.0S & 40.0 & car.d & $\tan \alpha$ & 215.0 & 표 D & $\mathbf{x a}$ & חס \\
\hline 2 & arlo & 5.43 & $\mathbf{2 0 . 0}$ & $1: 0.0$ & 154.0 & 200 & 49 & 400 & GID \\
\hline 3. & Andrijtes & 37.E & 120 & 50 & BS.D & IE.0 & 236.6 & 100.0 & Eण \\
\hline 4. & Trehjeה & 1.3 & 5.0 & Eid.0 & 24.0 & 120 & 200 & 4.0 & ताD \\
\hline 5 . & Cetio & 1.0 & 4.0 & 115.0 & kota & 4.0 & 4.0 & 1.5 & 5e्य.0 \\
\hline \multirow[t]{2}{*}{6} & Sjevemix & 5. 15 & 120 & 124.0 & $115 . a$ & 120 & ang & 2.0 & था \\
\hline & \multicolumn{6}{|l|}{ squ } & 30 & MrF.5 & $\mathbf{2 0 . 5}$ \\
\hline
\end{tabular}

Table 6. Variant 6 Predicts the Transfer of Upper Basin Water of the River Morača and Formation of a Big reservoir on the River Mrtvica in Velje Duboko without reservoir and HPP Bijeli Nerini and with the Normal Backwater Level of reservoir Andrijevo 250 m asl.

\begin{tabular}{|c|c|c|c|c|c|c|c|c|c|}
\hline$n$ & he of & 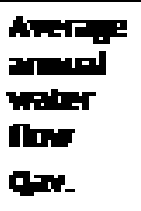 & 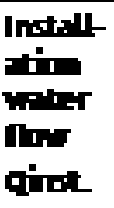 & (1) & $\begin{array}{l}\text { He } \\
\text { Inety }\end{array}$ & 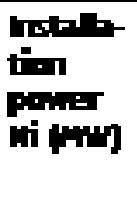 & 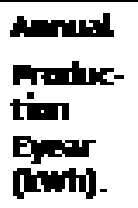 & 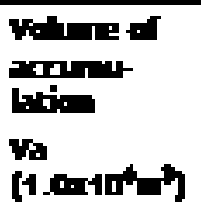 & $\begin{array}{l}\text { Mormal } \\
\text { borti- } \\
\text { vertit } \\
\text { lat }\end{array}$ \\
\hline & & en & P/s & n & n & $\mathrm{min}$ & Grh & ner & पn \\
\hline 1. & nelpe & 7.05 & 40.5 & 45 & fanda & 2ir.0 & 표1.0 & 500 & कृण \\
\hline 2 & arb & 5.43 & 30.0 & 1:D.0 & 154.0 & 260 & 49 & 40 & ERD \\
\hline 3. & Antijes & 37.E & 120 & 9:0 & F.s & 150.0 & 247.0 & 150.D & 245 \\
\hline 4. & Triving & 1.3 & 5.0 & Zid.D & 24.0 & 171 & 2hI & 4.0 & 开10 \\
\hline E. & OElo & 1.0 & 4.D & 115.0 & wata & 4.0 & 40 & 1.5 & 520 \\
\hline 5 & Sicilik & 5.1F & 720 & 124.0 & 115.9 & 171 & 89 & 2.0 & 110 \\
\hline & 도네 & & & & & 411 & FID. & 2 모.5 & \\
\hline
\end{tabular}

Table 7. Variant 7 Predicts the Transfer of Upper Basin Water of the River Morača and Formation of Big Accumulation on the River Mrtvica in Velje Duboko without reservoir and HPP Bijeli Nerini and with the Normal Backwater Level of reservoir Andrijevo $265 \mathrm{~m}$ asl.

Surely, the investigation with more answers would have better results but, in any case, we think that this is a great contribution for the pioneer attempt of the multicriteria optimization of variant solutions for utilization of hydroenergetic potential of the flows of the river Morača.

$\mathrm{F}(\mathrm{x})$ - Vector criteria function

$F(x)=f_{1}(x), f_{2}(x), f_{3}(x), f_{4}(x), f_{5}(x)$

The criteria functions in this paper are :

f1(x)- Annual production,

$\mathrm{f} 2(\mathrm{x})$-Volume of accumulation (reservoir),

$\mathrm{f}_{3}(\mathrm{x})$ - Installation power, $\mathrm{f}_{4}(\mathrm{x})$ - Negative influence on the environment, f5(x)- Sociological demands.

$\mathrm{x}$ - vector variables

For optimal solution we chose the method of compromise programming and compromise programming hierarchy.

The basic characteristics of compromise programming are the determination of minimum deviation from the ideal solution by the multicriteria optimization on the basis of the adopted distance measure, including all the criteria (Opricović 1992, Savić 2003, Steuer 1986). As distance measure from the ideal point in majority of cases Lp-metrics is used, as in this paper. 


\begin{tabular}{|c|c|c|c|c|c|}
\hline \multirow[t]{2}{*}{ The vriant malutions } & \multicolumn{5}{|c|}{ Arsifentim of variant onlutions - nne critsi function } \\
\hline & 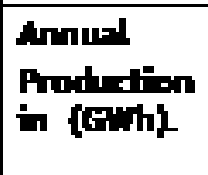 & 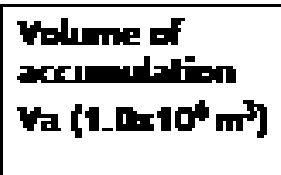 & 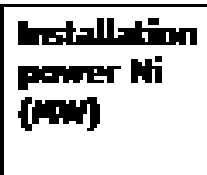 & 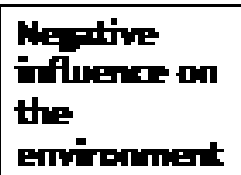 & 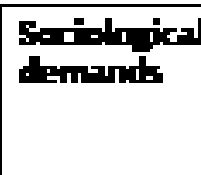 \\
\hline VADLAKTA I A1 & a47.100 & InL:00 & 표이 & 5.010 & 5.010 \\
\hline УADUAKTA 2 AZ & $87 \pi$ & 240110 & 20.000 & 1.00 & 1.110 \\
\hline Van LAKTA 3 A3 & 513.500 & 20100 & 26f5.40 & 300 & 2010 \\
\hline พanLuKTh 4 A4 & :Dr.50 & 25.110 & Sis.on & 300 & 3010 \\
\hline VAR LAKTA 5 & Ev.sen & 25.110 & 11k00 & 200 & 400 \\
\hline VATLAKTA A & Jueson & 24500 & Siscon & 2010 & 2010 \\
\hline WATLAKTA 7 & 750.50 & 29350 & Fiscol & 300 & 3010 \\
\hline
\end{tabular}

Table 8. Classification of for utilization of Hydroenergetic Potential of the Flows of the River Morača.

\begin{tabular}{|c|c|c|c|c|c|c|c|c|c|c|c|c|c|c|c|c|c|c|}
\hline \multirow[t]{2}{*}{ RL } & \multicolumn{3}{|c|}{ 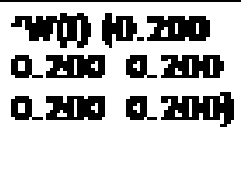 } & \multicolumn{3}{|c|}{ 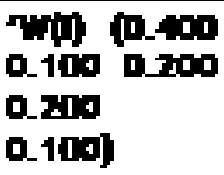 } & \multicolumn{3}{|c|}{$\begin{array}{l}\text { Wil) (0.210 } \\
0.300 \text { o.210 } \\
0.200 \\
0.100)\end{array}$} & \multicolumn{3}{|c|}{ 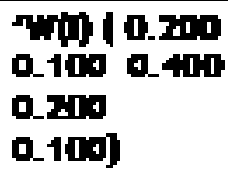 } & \multicolumn{3}{|c|}{ 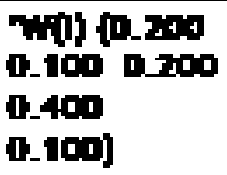 } & \multicolumn{3}{|c|}{ 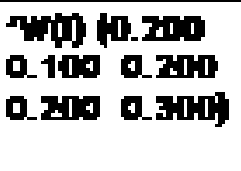 } \\
\hline & ax & $\mathbf{Q}$ & qS & वम & Q & 05 & Q & $\mathbf{Q}$ & $\mathrm{qS}$ & 91 & 9 & Qs & Qx & $\mathbf{Q}$ & as & वम & q & GS \\
\hline 1. & $\boldsymbol{H}$ & $\boldsymbol{M T}$ & A7 & $\mathbf{A P}$ & $A 7$ & $\mathbf{A 5}$ & $\boldsymbol{N T}$ & $\boldsymbol{N T}$ & A7 & A1 & A1 & $\boldsymbol{N}$ & 12 & $\boldsymbol{\Lambda}$ & A6 & $\boldsymbol{A} 7$ & $A$ & $\mathbf{M}$ \\
\hline 2 & $\mathbf{A 5}$ & $\mathbf{N F}$ & $\mathbf{M}$ & $A B$ & $A B$ & $M$ & $\mathbf{N 5}$ & $\mathbf{M S}$ & A5 & $\Delta 5$ & $\mathbf{A} 7$ & $\Delta 5$ & $\mathbf{N 3}$ & $\mathbf{N J}$ & $A T$ & $\mathbf{A 3}$ & $\mathbf{A A}$ & A7 \\
\hline 3. & $M$ & 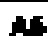 & $A 5$ & A4 & A1 & $\boldsymbol{N T}$ & $M$ & $\boldsymbol{N}$ & $\mathbf{M a}$ & $A 7$ & $A 5$ & Al & $\mathbf{M}$ & $\mathbf{M}$ & A4 & A4 & A1 & $\mathbf{A}$ \\
\hline 4. & $\mathbf{A 3}$ & $M$ & A1 & A1 & $\mathbf{A}$ & $\boldsymbol{N}$ & $\Delta$ & $\mathbf{M}$ & $\mathbf{M}$ & $\mathbf{A 3}$ & $\mathrm{AB}^{-}$ & $M$ & $\boldsymbol{M S}$ & 102 & Ar & $\boldsymbol{A Z}$ & $A \mathbf{A}$ & $A Z$ \\
\hline 5. & $\boldsymbol{H}$ & 10 & $A Z$ & $\mathbf{A}$ & A1 & A1 & A1 & $\mathbf{A 1}$ & A1 & $\mathbf{A Z}$ & $A$ & $\mathbf{M H}$ & $\boldsymbol{M}$ & $\mathbf{N 5}$ & AS & $\mathbf{A}$ & $A 5$ & $A 5$ \\
\hline 5. & $\boldsymbol{N 2}$ & $\mathbf{N 3}$ & A1 & $\mathbf{A 3}$ & $\mathbf{A 3}$ & 12 & $\boldsymbol{N 3}$ & 12 & $\mathbf{A Z}$ & A4 & $A$ & $\boldsymbol{N 2}$ & $\mathbf{M F}$ & $\mathbf{N 3}$ & $\mathbf{A 3}$ & $\Delta \boldsymbol{E}$ & $\mathbf{A 3}$ & $A 3$ \\
\hline 7. & Al & $\mathbf{A 1}$ & $\mathbf{A 3}$ & AZ & $A \mathbf{A}$ & A1 & 12 & $\mathbf{N 3}$ & $\mathbf{A 3}$ & $\mathbf{A B}$ & $A 7$ & $\mathbf{A 3}$ & A1 & A1 & A1 & A1 & A1 & A1 \\
\hline
\end{tabular}

Table 9. Classification of Variant Solutions on the Basis of Multi-criteria Optimization Process for Different Values of Weight Coefficients of Criteria Functions for Utilization of Hydroenergetic Potential of the River Morača.

$\mathrm{L}(\mathrm{FT}, \mathrm{F})=\quad ; \quad 1 \leq \mathrm{p} \geq$ :

As it can be seen Lp- metrics is the distance from the ideal point $\mathrm{F}$ and point $\mathrm{F}(\mathrm{x})$ in the space of criteria functions.

p- compromise parameter

The function compromise programming as $\mathrm{R}(\mathrm{F}(\mathrm{x}), \mathrm{p})$; $\mathrm{R}(\mathrm{F}(\mathrm{x}),:)=\max (\mathrm{fiT}-\mathrm{fi}(\mathrm{x}))$

In this research we use metrics for the following values of balancing factor:

$p=1$ the best solution for all of these five criteria

$\mathrm{p}=2$ the solution nearest to ideal point

$\mathrm{p}=$ : priority is given to the criterion with minimal deviation

Selection of the values of parameter $\mathrm{p}$ the strategy of compromise in multicriteria optimization is adopted.

For realization of this research we use the software designed for the solution of multicriteria optimization problems.

Results of Multicriteria Optimization and Rating

According to current Water Economy Base of Montenegro both Variants 1 and 2 are conditional and aim to determine limitary possibilities for realization of objects, on the basis of natural and other limitations. It should be mentioned that without the transfer of Monastery Morača could not be reached transfer in time of the River Morača neither in Variant 1 nor in Variant 2.

Criteria functions of negative influence on the environment and social demands, because of impossibility of obtaining exact results for each variant, are marked with numbers 1 to 5 , where the Variant marked with 5 has the lowest negative influence. 
On the basis of rating and criteria values, using software packages 'VIKOR' for problem solving in multi-criteria optimization and multi-criteria rating, the process of optimization for different values of weight coefficients was performed.

On the basis of extremization indicators for all variants according to analyzed criteria, the optimal sequence of variant solutions for each criterion was obtained; i.e., their places in classifications with one criterion (Table 8 ). The classification of variant solutions on the basis of multi-criteria optimization process for different values of weight coefficients of criteria functions Table 9.

If in the optimization process equal values of weight coefficients (W) I of criteria functions are introduced $0,20,2$ $0,20,2 \mathrm{O}, 2$, the results of vector-A are obtained according to the classification and measures $\mathrm{QR}, \mathrm{Q}, \mathrm{QS}$, where $\mathrm{QR}$ is a minimal strategy, $\mathrm{Q}$ is compromise list and QS is strategy of the majority of criteria (Table 9), and optimal solution for presented weight criteria is Variant 7.

VIKOR results for different values of weight coefficients of criteria functions W(I) classifications presented according to the measures QR, Q and QS

$\mathrm{QR}$ - minimal strategy

$\mathrm{Q}$ - compromise list

QS - strategy of the majority of criteria

If the accent is on weight coefficient of criteria function for annual production of electricity, the highest ranked variant is Variant 7, followed by Variant 5 and Variant 6 .

If the accent is on weight coefficient of accumulation volume in the process of multicriteria optimization, optimal solution is Variant 7, followed by Variant 5 and Variant 4.

If the accent is on total installed power in the process of optimization through weight coefficients, the highest ranked is Variant 1, followed by Variant 7 and 5 .

If the accent is on negative influence on the environment, optimal variant is Variant 6 , followed by Variant 7 and Variant 4.

If the accent is on weight coefficient of criteria functions of sociological demands, the highest ranked variant is Variant 7, followed by Variant 6 and Variant 4 .

\section{Conclusion}

For equal values of weight coefficients of criteria functions optimal solution is Variant 7. On the basis of presented investigations it can be concluded that before the final solution of hydro-energetic utilization of specific water flow it is necessary to carry out detailed analysis of all the potential variant solutions. The process of multi-criteria optimization and multi-criteria rating can be accomplished before making final deci- sions about the solution of hydro-energetic utilization of specific water flow.

In finding optimal solution for hydro-energetic utilization of water flow the most important factors are total annual production, accumulation volume and sociological demands. According to the analysis of the results of multi-criteria optimization for above mentioned criteria the highest ranked variant is Variant 7. If in the process of multi-criteria optimization the accent is on weight coefficient of criteria function of negative influence of reservoir on the environment, the highest ranked is Variant 6, followed by Variant 7 .

Regardless, the fact that only Variants 1 and 2 are included in the current Water Economy Base of Montenegro, it is necessary to do additional researches for other variant solutions, especially for variant solutions that provide transfer of upper course waters of the Morača river. These researches are particularly important because of the planned construction of a hydropower plant on the Morača river in near future. Therefore, these investigation papers will be very useful before making final choice of the variant solution on the basis of which will be constructed hydropower plants at this water course. Furthermore, this research is useful as a method which enables wide observation on finding optimal hydro energetic potential utilization of specific water flow.

If the accent is on weight coefficient of criteria function for annual production of electricity the highest ranked variants are Variant 5, followed by Variant 4, then followed by Variant A5.

If the accent is on weight coefficient of reservoir volume in the process of multicriteria optimization, optimal solution is Variant 4, followed by Variant 5 .

If the accent is on total installed power in the process of optimization through weight coefficients, the highest ranked is Variant 5 .

If the accent is on negative influence on the environment, optimal variant is Variant 4.

If the accent is on weight coefficient of criteria functions of sociological demands, the highest ranked variant is Variant 4, followed by Variant 3 and Variant A5.

Prof. Ratko Mitrović, Ph. d. teaches technology construction hydro power plants, construction management and technology, project management, construction estimating and property surveying. He has made designs and was superintendent, consultant for many different kinds of objects: hydro powers, residential buildings, railroads, roads, antenna, towers 
and stores. He undertook feasibility studies: plant for production of reinforced concrete piers for low and high voltage, plant for reparation of transformers and breakers and small hydro power plants Crnja, Ljubastica, Crni potok, and Trepacka Rivers. He has made original designs for more than 30 small hydro power plants. He has published widely both in Montenegro and abroad, and has also taken part in a number of conferences and symposia worldwide. He currently chairs the Department of Construction Management and Technology at the University of Montenegro.

Corresponding address: ratkom@ac.me

\section{References}

Brečević, D., D. Jug, E. Rojnik, A. Zapušek, A. Bučar, T. Cvetko, and M. Zeljko, 2007, Strategy for Energetic Development of the Republic of Montenegro Up to 2025, Podgorica, Montenegro: IREET (Institute for Research in Energy, Ecology and Technology), Developed for Government of Montenegro.

Divac, D., M. Milovanović, D.Zdravković, M. Milentijević and M. Popović, 2001, Water Management Base of the Republic of Montenegro (Hydroenergy Variant 1), Podgorica, Montenegro: Institute Jaroslav Černi, developed for the Government of Montenegro.

Divac, D., M. Milovanović, D.Zdravković, M. Milentijević and M. Popović, 2001, Water Management Base of the Republic of Montenegro (Hydroenergy Variant 2), Podgorica, Montenegro: Institute Jaroslav Černi, developed for the Government of Montenegro. Đorđević, B. and M. Šaranović, 2004, 'Hydrology Potential of Montenegro and Necessity of Their Fast Usage,' Pokgorica, Montenegro: CANU (Montenegran Academy of Sciences and Arts).

Đorđević, B., 1990, Systems of Water Resources Management, Belgrade: Faculty of Civil Engineering.

Đorđević, B., 2001, Hydro-Energetic Usage of Waters, Belgrade: Faculty of Civil Engineering.

Đorđević, B., 2003, Influences of Dams and Accumulation on the Social and Ecological Surrounding and Measures for Harmonious Dovetailing, Kladovo, Montenegro.

Đorđević, B., M. Šaranović: "Hydrologic potential of Montenegro", CANU (Montenegrin Academy of Sciences and Arts), Podgorica, 2007.

Opricović, S., 1986, Multicriteria Optimization, Belgrde: Faculty of Civil Engineering.

Opricović, S., 1992, System Optimization, Belgrade: Faculty of Civil Engineering.

Savić, L.J., 2003, Introduction to Hydro-Technical Structures", Belgrade: Faculty of Civil Engineering.

Steuer, R. J., 1986, Multiple Criteria Optimization: Theory, Computation and Application, New York: John Wiley.

Živaljević, R., 2006, Possibilities and Limits for Obtaining the Conditions for Usage of the Rest Usable Potentials of the Main Streams of Montenegro, Podgorica, Montenegro: Faculty of Civil Engineering, Water Resources Management.

\section{HYDR(ONepal}

\section{Call For Nomination for the Excellence Award 2011}

There are many people and institutions who have rendered their services in the pursuit of excellence in the field of water, energy and/or environment. The HYDRO Nepal Excellence Award is established to recognize their efforts and honor them. HYDRO Nepal journal solicits nominations from among the experts, professionals or other individuals/institutions involved in the pursuit of excellence in the field of water, energy, or/and environment in Nepal for the annual HYDRO Nepal Excellence Award for the year 2011.

Please send one page brief of the work and contributions of the nominated person or an institution for the year 2011 (and previous to that). Please include the nominee's full name, address, contact phone number and email address, including your own phone and email contact details. The deadline for submission of nominations is May 20, 2011.

Nominations will be evaluated by a three person Evaluation Committee consisting of prominent authorities in the sector. The Evaluation committee will decide the winner by June 30, 2011. The Decision of the Evaluation Committee will be final. The winner will be announced in the $9^{\text {th }}$ issue of HYDRO Nepal in July 2011.

\section{Address your nominations to: HYDRO Nepal}

P. O. Box: 15142 KPC 609, Kamalpokhari (near Kumari Hall), Kathmandu, Nepal Phone No.: 977-1-4430839, Email: hydro.nepal.journal@gmail.com 